\title{
WATAK DAN PERJUANGAN PEREMPUAN \\ DALAM NOVEL-NOVEL KARYA PENULIS PEREMPUAN INDONESIA \\ DAN MALAYSIA AWAL ABAD 21
}

\author{
Widyastuti Purbani \\ FBS Universitas Negeri Yogyakarta \\ Email: purbani@uny.ac.id
}

\begin{abstract}
Abstrak
Penelitian ini bertujuan mengidentifikasi dan mengungkap watak dan perjuangan tokoh wanita dalam delapan novel karya penulis wanita Indonesia dan Malaysia di awal abad 21. Penelitian ini penelitian kualitatif yang menggunakan metode penelitian isi. Temuan penelitian menunjukkan bahwa tokoh wanita dalam delapan novel tersebut merupakan wanita yang kuat dan tangguh yang hidup di masyarakat patriarkal yang diskriminatif, yang memandang wanita sebagai masyarakat kelas dua and objek hasrat seksual. Tokoh utama wanita dalam novel Indonesia dan Malaysia yang dikaji berjuang untuk diri mereka sendiri dan kaumnya melawan diskriminasi jender dan penyelewengan seksual. Ada tokoh wanita yang berjuang untuk meningkatkan pengetahuan dan keterampilan agar memperoleh kedudukan yang lebih baik, dan ada pula yang berjuang agar mendapatkan kesejahteraan ekonomi. Sementara tokoh Indonesia menggunakan hak asasi manusia untuk memperjuangkan persamaan jender dan keadilan moral, tokoh Malaysia menggunakan nilai keagamaan dan moral sebagai landasan perjuangan.
\end{abstract}

Kata kunci: perjuangan, tokoh wanita, diskriminasi jender, penyelewengan seksual

\section{WOMEN'S TRAITS AND STRUGGLES IN NOVELS WRITTEN BY INDONESIAN AND MALAYSIAN WOMEN WRITERS IN THE EARLY $21^{\text {ST }}$ CENTURY}

\begin{abstract}
This study aims to identify and reveal the traits and struggles of female characters in eight novels written by Indonesian and Malaysian women writers in the early $21^{\text {st }}$ century. This is a qualitative study employing content analysis. The study reveals that all main female characters in these eight novels are strong and tough women living in a discriminative patriarchal society in which women are seen as the second class society and object of sexual desire. The main female characters in the both Indonesian and Malaysian novels under study are fighting for either themselves or other female characters against gender discrimination and sexual abuse. Some female characters struggle to gain knowledge and skills for a better position, and some struggle to get economic welfare. While the Indonesian characters use human rights for gender equity and moral justice, the Malaysian characters use religious and moral conduct as the foundation for their struggle.
\end{abstract}

Keywords: struggle, female characters, gender discrimination, sexual abuse

\section{PENDAHULUAN}

Melakukan pembongkaran sekaligus pemaparan misogini dalam karya-karya yang selama ini telah dihasilkan oleh para penulis merupakan salah satu agenda pokok feminisme dalam sastra, sejak kemunculannya pada pertengahan abad 20. Merupakan fakta yang harus diakui bahwa sebagian besar penulis karya sastra adalah kaum laki-laki. Sekalipun tidak ada jaminan bahwa penulis laki-laki pastilah bias gender, seperti halnya tidak ada jaminan bahwa penulis perempuan pastilah adil gender, penulis laki-laki cenderung melakukan kesalahpahaman dalam mengungkapkan perasaan dan merepre- 
sentasikan perempuan. Perempuan sering direpresentasikan dan dicitrakan secara keliru oleh para penulis laki-laki, karena mereka memang tidak hidup dalam alam perempuan. Para penulis laki-laki pada umumnya menggambarkan perempuan melalui perasaan dan sudut pandang mereka, yang kadang-kadang bias, dan lebih berpihak kepada kaum mereka sendiri. Tidak sedikit penulis perempuan, yang hidup dengan alam pikiran patriarki pun sering melakukan hal yang sama. Perempuan sering mencitrakan diri mereka menggunakan cara berpikir laki-laki. Pencitraan yang mengandung stereotipstereotip seperti perempuan monster atau bidadari, pelecehan dan pemerdayaan perempuan melalui teks, dengan demikian merupakan hal yang perlu mendapat perhatian secara serius.

Agenda lain yang tidak kalah serius dari feminisme dalam sastra adalah promosi dan pemeriksaan tulisan-tulisan kaum perempuan, yang selama berabadabad terpendam dan hampir tidak memiliki suara akibat dominasi yang kuat dari penulis laki-laki. Moris (1993) mengemukakan bahwa setiap penulis memiliki gaya yang unik, tidak pernah ada yang sama. Tulisan-tulisan perempuan dapat mengungkapkan cerita-cerita mengenai aspek-aspek kehidupan perempuan yang pernah terhapus, tak terpedulikan atau disalahpahami oleh teks-teks tradisional, terutama yang ditulis oleh penulis laki-laki. Sekalipun disadari bahwa tidak semua penulis perempuan memiliki kesadaran gender yang baik, pengalaman batin dan perasaan khas penulis perempuan yang tertuang melalui tulisan-tulisan mereka merupakan suara yang patut dan bahkan penting untuk didengar dan dicatat. Paling tidak bagaimana perempuan digambarkan dan dicitrakan oleh perempuan sendiri dan bukan oleh kaum lain, merupakan informasi yang sangat penting.

Perkembangan 'nasib' perempuan yang telah mengalami kemajuan hingga abad ke 21 ini diasumsikan memiliki pengaruh yang cukup signifikan dalam penggambaran perempuan oleh penulis perempuan dewasa ini. Bagaimana perempuan-perempuan penulis merasakan dan terlibat dalam emansipasi dan perjuangan perempuan seperti tercermin dalam novel-novel mereka sesungguhnya merupakan refleksi dari ideologi teks, dan ideologi masyarakatnya. Karya sastra, termasuk novel, tidak pernah hanya berisikan cerita. Teks-teks tersebut merupakan situs berlangsungnya pertarungan ideologi, termasuk di antaranya ideologi gender.

Telah lama karya sastra digunakan sebagai arena persebaran ideologi gender. Pembaca yang kurang sadar dapat secara tidak sengaja mencerap dan mengusung ideologi gender, baik yang bersifat negatif atau positif, dari teks-teks tersebut. Itulah sebabnya salah satu agenda terpenting kajian sastra feminis adalah melakukan pembongkaran, menelanjangi teks, dan menemutunjukkan ideologi gender mereka di antaranya melalui perwatakan tokoh-tokoh perempuan, emansipasi dan penggambaran perjuangan mereka.

Dahulu dipercayai bahwa karya sastra bersifat universal, memiliki kebenarankebenaran yang mendunia. Kemudian disadari bahwa karya sastra juga bersifat unik dan individual. Kajian sastra bandingan memungkinkan untuk melihat sifat-sifat individual yang unik dari suatu karya sastra dalam persandingannya dengan karya sastra yang lain. Pada saat yang sama kajian ini juga dapat memperlihatkan sifat-sifat yang mirip dari beberapa karya sastra yang diperbandingkan. Kajian sastra bandingan, yang memiliki kemampuan menelusuri universalitas sekaligus keunikan beberapa karya sastra yang diperbandingkan menjadi alternatif peneliti yang berkeinginan melihat persamaan dan perbedaan karya-karya sastra tersebut. 
Era globalisasi membawa konsekuensi menipisnya batas, termasuk di antaranya batas wacana. Indonesia dan Malaysia merupakan negara bertetangga dekat dan bahkan 'bersaudara' karena sama-sama mendapat pengaruh budaya melayu. Indonesia dan Malaysia juga memiliki beberapa kemiripan 'pikiran dan perasaan' karena faktor sejarah dan letak geografis. Kajian-kajian yang melihat bagaimana penulis-penulis perempuan kedua negara itu menggambarkan pengalaman emansipasi dan perjuangan khas perempuan akan mengungkapkan seberapa dekat atau seberapa jauh penulis-penulis kedua negara tersebut memiliki persamaan dan perbedaan dalam membawa perubahan bagi perempuan-perempuan jamannya. (Gilbert, 1991)

Tulisan ini ingin membentangkan kajian bandingan novel-novel karya penulis perempuan Indonesia dan Malaysia yang difokuskan pada tiga pertanyaan penting. Pertama, bagaimanakah watak tokoh-tokoh perempuan yang terdapat dalam novel-novel karya penulis perempuan Indonesia awal abad 21 dan karya penulis perempuan Malaysia awal abad 21. Kedua, sejauh manakah keterlibatan tokoh-tokoh dalam novel-novel yang dikaji dalam memperjuangkan emansipasi perempuan. Ketiga, bagaimanakah perbedaan dan persamaan antara perjuangan tokoh-tokoh perempuan dalam novel-novel karya penulis Indonesia dan penulis Malaysia awal abad 21.

Kajian ini diharapkan dapat menemu-tunjukkan dan menganalisis watak tokoh-tokoh perempuan yang terdapat dalam novel-novel karya penulis perempuan Indonesia dan Malaysia awal abad 21. Kajian juga ingin mendeskripsikan keterlibatan tokoh-tokoh dalam novelnovel yang dikaji dalam memperjuangkan emansipasi perempuan. Disamping itu untuk membandingkan perjuangan dan emansipasi tokoh-tokoh perempuan dalam novel-novel karya perempuan
Malaysia dengan Indonesia dan melihat persamaan dan perbedaan perjuangan para tokoh perempuan tersebut.

Teori terbaru mengenai teks mengoreksi pengertian lama bahwa teks merupakan refleksi dari realitas. Pada kenyataannya beberapa teks justru memiliki kemampuan atau daya untuk membentuk realitas. Kemampuan teks membentuk realitas dikukuhkan oleh Fairclough (1992) yang menyatakan bahwa semua teks memiliki power atau kuasa untuk mengkonstruksi. Hal ini juga ditegaskan oleh baik Hollindale maupun Stephens yang menyatakan bahwa 'ideology is inherent within language', dan karena teks memuat ideologi maka ia berpotensi untuk membentuk subjektivitas seseorang.

Kemampuan teks untuk mengkonstruksi subjektivitas gender sebenarnya telah dibuktikan oleh banyak pihak. Makna perempuan atau kualitas yang melekat pada kata perempuan telah diproduksi oleh dan melalui bahasa teks. Hal yang hampir sama juga dikemukakan oleh Moris (1993) yang menyatakan bahwa 'What we consider to be manly may derives as much from the way in which masculinity is imagined for us through stories, picture and the medias". Apa yang dipahami mengenai kelelakian kemungkinan telah diperoleh dari bagaiman konsep maskulinitas dicitrakan bagi kita melalui cerita-cerita, gambar, buku maupun media, karya sastra yang kita baca/lihat. Demikian pula, pengertian bahwa perempuan merupakan makhluk yang lemah dan bergantung telah secara berangsur-angsur dicitrakan, dibentuk dan dikukuhkan oleh teks-teks yang beredar dan dibaca oleh masyarakat.

Ideologi berarti makna yang mengabdi pada power/authority. Power atau authority penulis teks tercurah ke dalam teks manakala ia menentukan fakta-fakta apa yang ditulis/ditonjolkan/divokalisasikan dari data-data yang dimilikinya, $\sim$ faktafakta apa yang tak ditulis/disembunyikan/ dikesampingkan, sudut pandang/angle

Watak dan Perjuangan Perempuan dalam Novel-novel Karya Penulis Perempuan Indonesia... 
mana yang diambil, plot (termasuk tikai-an dan ending) yang digunakan, rbahasa/ekspresi/diksi dan gaya bahasa seperti apa yang digunakannya, narasi yang digunakan untuk menuturkan, judul seperti apa yang digunakannya. Yang kesemuanya berpengaruh terhadap tampilan dan kan-dungan teks. Dengan kata lain penulis termasuk di antaranya penulis karya sastra merupakan the authoritative figures, karena mereka berada pada posisi someone who knows/who has the facts dan terlebih dari itu whohas the right to tell (Fiske, 1995; 1982)

Teks termasuk karya sastra dengan demikian merupakan teks yang tidak bebas nilai, karena ia tidak sekadar memuat fakta/informasi murni, namun memuat ideologi-ideologi yang melekat pada how the fact is represented. Ideologi tersebut bisa amat tampak maupun amat tersembunyi/ hidden. Terhadap ideologi yang eksplisit ini, pembaca bisa dengan gampang mengenali, namun terhadap yang tersembunyi, hanya mereka yang memiliki kepekaan yang mampu merasakannya (Hollindale, 1988; Stephens,1992)

Mengingat sejarah panjang subordinasi perempuan dan ketimpangan gender dalam teks, Morris menyatakan sebagai berikut:

Creative forms of writing can offer special insight into human experience and sharpen our perception of social reality. Literary texts may, therefore, provide a more powerful understanding of the ways in which society works to the disadvantage of women. In addition, the strong emotional impact of imaginative writing may be brought into play to increase indignation at gender discrimination and hence help to end it. Positive images of female experience and qualities can be used to raise women's self esteem and lend authority to their political demands (1993:7).

Subordinasi perempuan dan ketimpangan gender yang bertumbuh kembang dalam masyarakat menurut Bronwyn (1993) telah diakibatkan oleh terbangunnya dunia bipolar-heteroseksual dalam teks-teks yang beredar dalam masyarakat. Lebih jauh Bronwyn menegaskan (1993:12) bahwa makna yang kita punyai mengenai pria dan wanita selama ini telah berlandaskan pada asumsi bipolaritas dari perbedaan-perbedaan fisiologis yang disebutnya sebagai 'faulty science' atau pengetahuan yang keliru. Belajar dari kesalahan itu, sebetulnya individu tidak lagi perlu dilihat sebagai 'a unitary, unproblematically sexed being' yang fixed tetap atau mati tetapi merupakan 'a shifting nexus of possibilities' yang lebih cair/lentur dan bisa saling dipertukarkan. Teks sebaiknya tidak melakukan pengulangan kesalahankesalahan yang telah dibuat selama ini, yang akhirnya telah menelurkan suatu masyarakat yang patriarkis, di mana di satu sisi laki-laki memiliki otoritas dan power yang kuat sedangkan di sisi lain wanita lemah dan bergantung padanya

\section{METODE}

Penelitian ini merupakan kajian deskriptif kualitatif dengan metode analisis isi dengan berpijak pada teori feminisme dalam sastra sebagai panduan. Kajian ini dilakukan terhadap delapan novel yang diambil secara acak dari sejumlah novel karya penulis perempuan awal abad $21 \mathrm{di}$ kedua negara. Kedelapan novel tersebut terdiri dari 4 novel karya penulis perempuan Indonesia dan 4 novel karya penulis perempuan Malaysia yang ditulis pada awal abad kurun waktu 2000-2005. Karya awal abad 21 ini dipilih karena peneliti ingin melihat perkembangan dan wawasan gender terkini novel-novel karya penulis perempuan dari 2 negara. Novelnovel karya penulis Indonesia yang dijadikan objek penelitian, yaitu (a) Nayla karya Djenar Maesa Ayu tahun 2005, (b) Geni Jora karya Abidah El Khalieqi tahun 2004, (c) Atap karya Fira Basuki tahun 2002, dan (d) Larung karya Ayu Utami tahun 2001. 
Sementara itu, novel-novel karya penulis Malaysia yang dijadikan objek penelitian, yaitu (a) Haruman Kencana karya Zaharah Nawawi tahun 2004, (b) Syumul karya Ashmah Nordin tahun 2002, (c) Trilogi Khadijah Hashim karya Khadijah Hashim tahun 2000, dan (d) Salam Maria karya Fatimah Busu tahun 2000

Data yang akan dikaji dari novel-novel di atas berupa kata, kalimat, ungkapan baik yang bersifat denotatif maupun konotatif yang berkaitan dengan aspek watak tokoh, emansipasi dan perjuangan perempuan.

Karena penelitian ini bersifat interpretatif, instrumen utama penelitian ini adalah peneliti sendiri yang akan menggunakan kapasitasnya, pengetahuannya dan logika/penalarannya untuk menginterpretasikan data-data tersebut di atas. Kartu data dan tabel bandingan akan digunakan untuk memudahkan analisis data.

Masing-masing novel yang diteliti akan dibaca berulang-ulang untuk memperoleh peta data yang jelas. Kemudian data yang berwujud kata/frasa/ungkapan atau kalimat tersebut dicuplik dan dikumpulkan dalam kartu atau tabel. Kemudian terhadap data-data tersebut dilakukan reduksi data, yakni pemilihan data-data yang benar-benar relevan dan pembuangan data yang dianggap kurang relevan. Setelah tahapan reduksi data tersebut ditempuh berlandaskan kerangka teori yang diacu dilakukan kategorisasi data, yakni pemilahan dan pengelompokan data. Tahapan berikutnya adalah interpretasi atau pemaknaan data sesuai kelompok/kategori masing-masing. Untuk menjawab pertanyaan mengenai perbandingan, data-data yang diperoleh dari novel-novel karya penulis Indonesia akan dibandingkan, dicari persamaan dan perbedaannya, untuk kemudian diinterpretasikan dan didiskusikan.

Trianggulasi penelitian dilakukan menggunakan teknik intra dan ektrarater, yakni meminta peneliti dari Malaysia untuk membaca dan memberi komentar terhadap pembahasan yang dilakukan, dan kemudian memperbandingkan bahasan tersebut dengan tulisan-tulisan lain yang berkaitan dan relevan dengan tema penelitian ini.

\section{HASIL DAN PEMBAHASAN}

Pada bagian ini akan dipaparkan kajian terhadap watak dan perjuangan tokohtokoh dalam novel-novel Indonesia, yang akan diikuti oleh kajian terhadap watak dan perjuangan tokoh-tokoh pada novelnovel Malaysia. Subbagian berikutnya merupakan kajian bandingan dari kedua kelompok novel tersebut.

\section{Watak dan Perjuangan Tokoh Perem- puan dalam Novel-Novel Indonesia awal Abad 21}

Para tokoh perempuan dalam novelnovel yang dikaji merupakan pribadipribadi yang kompleks, bukan sosok yang mudah ditebak. Mereka memilki watak yang multidimensional, bukan watak yang hitam-putih. Sebagai novelnovel realis, penokohan serupa memiliki tingkat kepercayaan yang cukup tinggi. Tokoh-tokoh berdimensi banyak tersebut merupakan potret jujur manusia-manusia yang hidup dalam alam nyata dengan segenap problematikanya.

Pada umumnya para tokoh utama 4 novel Indonesia yang dikaji menunjukkan sifat-sifat cerdas dan kritis. Sekalipun tidak semua di antara mereka berpendidikan tinggi (misalnya Nayla), mereka bukan termasuk tipe perempuan bodoh yang mudah terkecoh oleh pengelabuanpengelabuan dan iming-iming yang menggoda dari berbagai pihak. Mereka rasional dan menggunakan akal sehat dalam menghadapi dan memecahkan masalah. June, misalnya tidak gegabah menentukan bakal suaminya, sekalipun sudah berada di pelukan Aji Saka yang ia cintai dan mencintainya dengan sepenuh hati, memperlakukannya bak ratu,

Watak dan Perjuangan Perempuan dalam Novel-novel Karya Penulis Perempuan Indonesia... 
memberinya hadiah-hadiah gemerlap (apartemen dan restoran). Sekalipun sempat terpesona dengan kehebatan Aji, melalui pemikiran dan pertimbangan yang matang, ia meninggalkan Aji dan apartemen yang telah diberikan Aji kepadanya sebagai hadiah:

Aku meninggalkannya sekali lagi. Jawaban itu kutemukan. Aku ke Boulder untuk memastikan apakah aku mencintainya. Jawabannya ya. Apakah cintaku cukup besar untuk menikahinya? Jawabannya: tidak. Mengapa? Aku tidak bisa bertahan dengan orang seperti Aji.... (Basuki:186)

Maka ia kembali kepada Jigme, lakilaki Tibet yang sederhana, tidak terlalu bergelora, tetapi lebih tepat untuk menjadi 'atap hatinya'.

Aku telah pulang Mas Bowo. Kembali pada suamiku, tempatku berada. Aku menemukan atapku (Basuki:193).

Demikian juga Jora. Ia tidak demikian saja diperdaya oleh Zakki yang memiliki kepiawaian dalam banyak hal termasuk untuk mengelabui perempuan. Jora harus melakukan pembalasan setimpal untuk menghajarnya dan mengubah pikiran Zakki, sebelum pada akhirnya menerimanya. Bagi Jora: 'perempuan tidak bisa dibohongi, tidak layak dibohongi dan bukan obyek dari kebohongan. Menipu perempuan adalah sama dengan menipu diri sendiri. Sekaligus menipu dunia' (Khalieqi: 10).

Para tokoh utama perempuan dalam novel-novel yang dikaji ini merupakan sosok-sosok yang berani dan terbuka. Mereka bukan tipe perempuan muda yang penakut dan pasif menunggu datangnya kesempatan, melainkan perempuanperempuan muda yang menentukan dan mengambil sikap. Mereka memahami resiko dari sikap yang mereka ambil. Nayla misalnya, berdasarkan keyakinan dan pengalamannya berani menentukan orientasi seksnya sendiri meskipun ia mengambil resiko dibenci dan dihina oleh masyakarat di sekitarnya.

Maka, dalam waktu sesingkat itu tak ada satupun yang bisa memuaskan saya seperti Juli, tetapi memang bukan sekadar kepuasan kelamin yang saya cari. Saya butuh kepuasan rohani..... Bersama Juli saya merasakan kehangatan kasih yang pernah ingin saya berikan kepada Ibu..... Lebih baik saya memilih mencintai Juli ketimbang laki-laki yang menginginkan selaput dara saya (Ayu: 101, 5, 6)

Penjelasan Nayla pun cukup rasional: ia disalahpahami, selama itu ia senantiasa dikecewakan dan dijadikan budak nafsu oleh banyak laki-laki, dan hanya Juli (yang kebetulan berjenis kelamin perempuan) lah yang mampu memahami jati dirinya, merupakan tempat berlabuh yang lebih nyaman baginya. Resiko yang Nayla ambil sangat jelas: stigma lesbian yang masih dipandang buruk di tengah masyarakat Indonesia pada umumnya.

Jora juga merupakan wanita yang berani memberontak tatanan yang selama itu dijadikan panutan di lingkungan pesantren dan keluarganya sendiri. Ia mengambil resiko dihukum oleh ustadz dan orang tuanya sendiri. Dalam kesempatan ujian yang dilakukan di pesantren, secara berani Jora menjawab pertanyaanpertanyaan Ustaznya sbb:

"Sebutkan hal-hal yang membatalkan salat"

"Hanya satu hal Ustaz"

"Sebutkan"

Aku mendehem dan memandang ragu ke arah Ustaz Mu'ammal yang tak acuh dengan soalnya. Pedulikah ia dengan jawabannya?

"Tidak memiliki imajinasi" 
Mendongak kaget beliau. Ia menyuruhku mengulagi.

"Tidak memiliki imajinasi"

Beliau tertawa dan memintaku menerangkan makna dari jawabanku.

"Seseorang yang tidak memiliki imajinasi, ia tidak pernah bisa salat. Jika pun melaksanakan salat, itu hanyalah ritual kosong yang bisa dilaksanakan oleh semua robot. Hanya orang yang memiliki imajinasi yang bisa melaksanakan dan benar-benar salat"(Khalieqy:33)

Lepas dari isi argumennya, Jora menunjukkan keberanian untuk berargumen dan mengkritisi orang yang oleh khalayak pesantren dianggap memiliki otoritas yang tak terbantahkan.

June harus mengorbankan banyak uang dan waktu untuk meyakinkan hatinya akan orang yang paling dicintainya dan paling layak untuk menjadi 'atap' dalam hidupnya. Ia meninggalkan Jigme dan pergi ke Amerika hanya untuk menetapkan hatinya mengenai siapa bakal suami yang benar-benar sesuai katahatinya.

Yasmin, kecuali berprofesi sebagai pengacara handal yang dihormati, juga merupakan aktivis dan pejuang hak asasi manusia yang berani. Ia mendukung gerakan bawah tanah dan berbicara lantang tentang hak-hak kaum tertindas, khususnya kaum perempuan. Bersama temannya (juga perempuan) ia melindungi dan menyembunyikan Saman, salah satu aktivis korban kerusuhan Mei yang diburu pemerintah, dan menyelundupkkannya ke Medan lalu ke New York. Bersama Larung ia memimpin penyembunyian 3 tokoh PRD yang melibatkan Saman. Ia berani mengambil resiko ditangkap dan dipenjarakan karena perbuatannya. Bagi para aktivis HAM, Yasmin adalah pahlawan.

Para tokoh memiliki wawasan global. Mereka sangat mobile, berusaha untuk mendapatkan akses untuk menjelajah dunia hingga ke luar negeri (kecuali Nay- la), dan berinteraksi dengan orang-orang dari berbagai bangsa dan latar belakang budaya tanpa mengalami kesulitan. Jora mengunjungi Damaskus dan Maroko, dan menimba ilmu di sana. Ia bergaul akrab dengan kalangan yahudi. Ia sangat mengagumi lagu-lagu dan masakan timur tengah yang dianggapnya eksotis. Bagi June hidup dan bergaul dengan masyarakat Amerika adalah bagian hidup yang penting dan pantas dinikmati. Ia banyak menghabiskan waktu di China, New Jersey, Kansas, Chicago, New York, tapi menikah dengan orang Tibet dan hidup di Singapura. Bagi Yasmin, New York bagai rumah keduanya. Nayla sekalipun tidak digambarkan sangat mobile, memiliki teman bergaul yang sangat variatif mulai dari kalangan artis, seniman, penulis, wartawan, pengusaha hingga pemabok, bencong.

Hampir semua tokoh ini mandiri, atau setidaknya berproses menuju kemandirian sosial dan finansial. Mereka bukan tipe perempuan yang bergantung kepada pihak lain, terutama laki-laki yang dekat dengan mereka, dan mampu memerdekakan diri mereka secara finansial untuk mencapai keinginan-keinginan mereka. Akses finansial mereka ini merupakan alat untuk mencapai kemandirian sosial mereka (June, Yasmin, Jora). Karena tidak memiliki pekerjaan tetap Nayla memiliki ketergantungan finansial kepada Juli kemudian ibu tirinya karena kebiasannya minum dan memanjakan dirinya yang berlebihan. Ketergantungan finansial ini menyulitkan Nayla dalam melakukan hal-hal yang dikehendakinya.

Para tokoh menghadapi tantangan sosial yang cukup serius. Hampir semua tokoh berhadapan dengan masyarakat yang secara umum masih memiliki pandangan yang patriarkis, yang menempatkan perempuan pada posisi subordinat sebagai objek. Terutama Nayla. Tokoh Nayla menghadapi penyiksaan fisik dan psikologis yang sangat berat akbibat dari

Watak dan Perjuangan Perempuan dalam Novel-novel Karya Penulis Perempuan Indonesia... 
kemurkaan dan kepedihan (terhadap lakilaki) yang diderita ibunya sendiri. Secara simbolik penyiksaan ini diungkapkan dengan tusukan peniti pada liang vagina (Ayu:1-3)

Nayla Ia juga mengalami pelecehan seksual yang traumatik dari pacar ibunya. Deskripsi realitas tersebut tampak pada kutipan berikut.

Saya takut mengatakan apa yang pernah dilakukan Om Indra kepada saya. Padahal saya ingin mengatakan kalau Om Indra sering meremas-remas penisnya di depan saya hingga cairan putih muncrat dari sana. Bahkan ketika kami sedang sama-sama nonton televisi dan Ibu pergi sebentar ke kamar mandi, Om Indra kerap mengeluarkan penis dari dalam celananya hanya untuk sekejap menunjukkannya kepada saya. Om Indra juga sering datang ke kamar saya ketika saya belajar dan menggesek-gesekkan penisnya ke tengkuk saya. (Ayu:113)

Sejak kecil ia juga hidup dan dibesarkan dalam alam di mana perempuan tak lebih dari sekadar objek seks belaka. Nayla juga memiliki problema ekonomi yang serius sejak kecil hingga remaja, sementara di hadapan matanya ibunya mempertukarkan layanan seks dengan materi, yang menyebabkan Nayla menjadi pribadi yang frustrasi. Dalam novel ini Nayla merupakan korban kebiadaban patriarkhi yang luar biasa. Itulah sebabnya hingga akhir cerita tokoh Nayla masih tampak gamang menghadapi hidup yang kejam, dan belum mampu keluar dari bayang-bayang masa lampau yang traumatik.

June juga dibesarkan dalam keluarga di mana ibunya sangat menikmati hidup sebagai penyenang suami, sehingga kecantikan dan kekencangan tubuh sangatlah penting. 'Mama memang cantik. Seharusnya ia tidak perlu meminta dokter untuk injeksi ini itu, meminta pil ajaib atau memolskan krim wajah termahal' (Basuki: 195). Kakak June juga seorang poligamis. Untungnya June memiliki kecukupan dalam hal finansial, sehingga belajar di luar negeri tidak menjadi kendala baginya.

Orang tua dan keluarga besar Jora masih memiliki pandangan bahwa kaum perempuan tidak harus belajar tinggi, karena bagaimanapun kepemimpinan ada di tangan laki-laki. Neneknya bahkan mengajarkan bahwa perempuan 'harus mengalah', itulah yang telah ia lakukan selama berpuluh tahun sepanjang hidupnya, karena laki-laki tidak boleh mengalah. Jora juga hidup dalam keluarga di mana poligami adalah hal yang lumrah. Ibunya sendiri tulus iklhlas menjadi isteri pertama. Jora dan Lala hidup dalam pengawasan yang ketat, dan dikitari laki-laki yang memandang perempuan sebagai objek seksualitas belaka. Omnya sendiri sering melakukan pelecehan seksual kepada mereka, bahkan hampir memperkosa mereka. Kepandaian dan keberanian Joralah yang menggagalkan niat bejat tersebut. Hal ini pulalah yang kemudian membuatnya berkeinginan membuktikan bahwa kata-kata neneknya tentang kelemahan perempuan tidaklah benar.

Yasmin kecil dan gadis-gadis seusianya harus kehilangan identitasya sebagai perempuan untuk memasuki dunia wanita yang menjadikan mereka lebih sebagai obyek (seksualitas). Perubahan identitasnya dari perempuan menjadi wanita telah memasungnya dan menjadikannya pribadi taklukan yang lemah:

Lalu suatu pergeseran yang aneh terjadi. Adakah aku menghukum diriku sendiri, ataukah ia datang bersama masa awalku memasuki dunia patriarkal yang tak kuketahui, dunia di luarku yang memaksakan dir, di mana wanita adalah obyek seksualitas? Aku kehilangan kesubyekan pada kepe- 
rempuananku dan menjadi wanita. Dalam proses yang tak kumengerti, aku mulai menempatkan diriku sebagai si terhukum wanita yang dikutuk karena kewanitaannya. (Utami:158)

Seperti dipaparkan di atas para tokoh perempuan ini menghadapi problema diskriminasi, subordinasi dan kekerasan (fisik dan simbolik) masyarakat patriarki karena keperempuanan mereka. Perjuangan mereka adalah perjuangan menghadapi dan menghapus diskriminasi, subordinasi dan kekerasan tersebut. Perjuangan tersebut secara jelas dilakukan oleh Nayla dalam menghadapi para laki-laki yang menganggap dirinya budak nafsu seks belaka. Sekalipun ia juga sering tidak berdaya dalam menghadapi kekerasankekerasan mereka, yang menjadikannya gadis yang berperangai buruk namun kebencian dan penolakannya terhadap laki-laki merupakan refleksi resistansi tersebut. Sekalipun ia tidak selalu berhasil menempatkan diri sebagai subyek, tapi ia memiliki keberanian untuk mengartikulasikan perasaan dan penilaiannya. Perasaan dan penilaiannya sering ia ungkapkan dalam tulisan-tulisan dan naskahnaskah filmnya yang kritis.

Perjuangan Jora adalah perjuangan meruntuhkan diskriminasi yang bersemi dari keluarganya sendiri (terutama neneknya). Ini ditunjukkannya dengan ketekunannya belajar, berargumen, memimpin yang membawanya kepada kesempatan yang lebih besar (belajar di luar negeridan berkiprah di forum internasional). Salah satu perjuangannya adalah menyadarkan laki-laki yang ada di sekitarnya (termasuk Zakki) akan posisi mereka yang tidak subordinat.

Perjuangan Yasmin dieskpresikannya dengan berbagai cara. Perjuangan dalam melawan kekerasan terhadap perempuan sangat nyata. Ini ia tunjukkan dalam pembelaannya kepada kaum lemah dalam kapasitasnya sebagai pengacara, serta melalui kontribusinya dalam berbagai gerakan bawah tanah melawan penguasa yang diskriminatif. 'Perjuangan'nya melawan eksploitasi, kekerasan dan penempatan perempuan sebagai obyek seksual direflesikannya dalam 'pemerkosaannya' terhadap Saman. Dengan Saman ia dapat merayakan ekspresi libido purbanya yang pernah hilang 'dirampas' konstruksi patriarki.

Jika emansipasi diartikan sebagai pembebasan dari tekanan-tekanan politik, sosial maupun ekonomi yang tidak mengenakkan (Collis Cobuild), maka semua tokoh utama perempuan dalam novelnovel ini telah melakukan dan terlibat secara langsung dalam upaya emansipasi, baik untuk diri mereka sendiri maupun bagi masyarakat di sekitarnya. Sekalipun tidak semuanya menemukan kejelasan (Yasmin dan Nayla), pada akhir cerita para perempuan ini nyaris terbebas dari jeratan-jeratan (terutama sosial) yang membelenggu di sepanjang perjalanan hidup mereka. Pada akhir cerita, mereka memiliki kemandirian dan keyakinan akan posisi mereka dalam masyarakat. Beberapa tokoh seperti Jora, June dan Yasmin bahkan menjadi transeter bagi masyarakatnya. Jora dan terutama Yasmin aktif secara langsung dalam kegiatankegiatan yang berurusan dengan agenda pemberdayaan dan penyadaran hak-hakkaum tertindas terutama perempuan. Jora terlibat dalam konferensi pemberdayaan perempuan internasional. Lewat tulisantulisannya yang kritis June menerangi masyarakat akan berbagai kesalahpahaman hubungan gender. Dalam wawancara dengan suatu majalah, Nayla menyatakan penilaian sekaligus pendapatnya yang kritis mengenai tubuh perempuan:

'Tubuh perempuan direpresi dan hanya difungsikan sebagai alat reproduksi. Tubuh perempuan tidak diberi hak bersenang-senang atau disenangkan. Perempuan harus per-

Watak dan Perjuangan Perempuan dalam Novel-novel Karya Penulis Perempuan Indonesia... 
awan. Perempuan harus bisa hamil dan melahirkan. Perempuan harus menyusui. Perempuan harus pintar memuaskan laki-laki di ranjang. Perempuan hanya masyarakat nomor dua setelah laki-laki. Coba bayangkan, banyak sekali perempuan yang tidak tahu seperti apa sesungguhnya orgasme. Ini kan menyedihkan sekali' (Ayu: 117)

Namun emansipasi tersebut bagi mereka bukan hadiah yang datang secara tiba-tiba. Para tokoh ini harus melakukan perjuangan-perjuangan yang cukup keras dan tak kenal menyerah guna mencapai titik tersebut.

Watak dan Perjuangan-Tokoh Perempuan dalam Novel-Novel Malaysia Awal Abad 21

Tokoh-tokoh perempuan dalam 4 novel Malaysia yang diteliti menunjukkan sifat-sifat yang kuat. Mereka bukanlah perempuan-perempuan patriarki. Mereka justeru para perempuan yang telah memiliki kesadaran gender yang setara. Mereka tidak takluk pada tatanan patriarki yang mendiskriminasi kaumnya, bahkan menunjukkan perlawanan terhadap ketidakadilan.

Maria Zaitun dalam Salam Maria, misalnya digambarkan sebagai seorang muslim yang taat dan taqwa, pemimpin spiritual, pengusaha yang gigih mendampingi kaum perempuan terpinggirkan untuk bangkit melalui usaha kecil rumah tangga: menjahit, menyulam kain telekung untuk dijual. Lewat cara-cara yang penuh kasih, ia memberdayakan kaum perempuan papa yang kurang atau bahkan luput dari perhatian pemerintah. Melalui usaha kecil tersebut para perempuan binaannya menjadi kelompok yang mandiri baik secara finansial maupun sosial. Mereka tidak lagi harus bergantung kepada suami atau keluarganya, dan oleh karenanya mereka bebas dari segenap ke- tertindasan yang menyakitkan.Agama (Islam) menjadi watak inti dari Maria Zaitun dalam melakukan kegiatan-kegiatannya. Dalam berbagai keputusan yang ia ambil, ia selalu menggunakan panduan agama yang dianutnya.

"Penjara sampai mati atau bunuh terus. Dalam Al-Quran, sesiapa lelaki melakukan zina dengan mahramnya sama sahaja hukumannya seperti orang murtad, kena bunuh. Kalau pasagan berzina yang belum pernah kahwin kena sebat 80 kali, lepas itu buang daerah. Kalau buat hukuman macam tu batulah orang serik" (Busu, 457)

Pertikan di atas menunjukkan kekesalan Maria Zaitun terhadap lak-laki yang berbuat zina. Dia menggunakan Al-Quran sebagai pegangan dalam melakukan penilaiannya terhadap pelaku kejahatan.

Dalam perjuangannya, Maria Zaitun mengalami perlawanan justeru dari para imam masjid negara, pemimpin keagamaan Islam sendiri, yang hidup dalam perspektif patriarki yang kental. Para imam dan tokoh agama ini kecuali sering bertindak sewenang-wenang terhadap kaum perempuan juga digambarkan kurang peka terhadap persoalan-persoalan kemanusiaan yang diderita umat mereka. Mereka menafsirkan praktik beragama secara harafiah. Bukannya membantu usaha Maria mengentaskan kemiskinan, para imam yang congkak tersebut justeru mengusir Maria dari masjid tempatnya berlindung karena Maria dituduh sebagai perempuan kotor dan tak bermoral. Maria disalahpahami. Namun persahabatannya dengan kaum perempuan di Hutan Beringin yang ditolongnya membuatnya lebih kuat. Persoalan lain yang dihadapi Maria dalam perjuangannya datang dari Siti Senang, perempuan wartawan majalah Primadona, yang dengan tujuan popularitasnya sendiri mendramatisir dan mengumbar sensasi atas usaha-usaha 
Maria. Sekalipun ia meninggal secara menyedihkan, dan dimakamkan oleh kaum papa, Maria telah meninggalkan semangat kebangkitan di kalangan kaum perempuan yang dibimbingnya.

Dalam Haruman Kencana, tokoh Dr. Farhana digambarkan sebagai perempuan mandiri, cendekiawan berwawasan global dan berperspektif futuristik. Kecuali itu, ia juga memiliki memiliki semangat membimbing dan mendidik yang sangat baik. Ia lah yang menjadi inspirator sekaligus mentor bagi tokoh utama novel ini, yakni Kencana. Melalui bimbingan dan arahannya, Kencana yang pada awalnya hanyalah gadis biasa yang naif dan inosen berhasil mencapai cita-citanya sebagai peneliti sekaligus pengusaha berkelas internasional dalam bidang pembuatan minyak wangi. Minyak wangi yang diproduksi Kencana dan Dr. Farhana merupakan parfum yang halal, memiliki mutu yang tinggi sehingga dapat menembus pasaran dunia yang terkenal diwarnai persaingan yang ketat. Kencana tumbuh menjadi wanita peneliti intelek yang sangat dinamis yang mampu bermain dalam percaturan dunia. Baginya melanglang buana ke negara-negara Eropa, khususnya Perancis adalah bagian dari kesibukan sehari-hari.

Baik Dr. Farhana maupun Kencana berjuang melawan tantangan-tantangan pasar global yang tidak mudah ditaklukkan. Perasaan lekas merasa puas dan menyerah dalam menciptaan produk yang benar-benar bermutu, persaingan dagang yang ketat dan kelicikan-kelicikan kapitalisme telah membuat dua perempuan ini semakin tangguh.

Para perempuan dalam novel-novel Malaysia berjuang untuk mendapatkan ilmu pengetahuan. Hal tersebut tampak sekali dalam novel Haruman Kencana. Dr. Farhana memandang penting kapakaran dan oleh karenanya memprioritaskan mereka-mereka yang memang ahli dan berpengetahuan, sekalipun kondisi terse- but harus dipenuhi lewat proses yang lama, yaitu kursus atau pendidikan. Ia percaya bahwa pendidikan mampu membuat seseorang profesional dalam melakukan tugas dan tanggung jawabnya.

\begin{abstract}
"Sebaik-baiknya kita ambil pakar dalam Negara. Jika memang belum ada pakar membat minyak wangi di sini, kita cadangkan kita latih seseorang yang berpotensi kagi berbakat besar. Selain memikirkan jauh kehadapan atau berwawasan kita wajar membna kejujuran. Maaf saya tidak bermaksud pakar Grasse tidak jujur, tetapi kejujuran yang dimaksud adalah dari SHB sendiri." (Zaharah Nawawi: 15)
\end{abstract}

Perjuangan untuk mendapatkan pengetahuan juga dilakukan oleh Maria Zaitun dalam Salam Maria. Novel tersebut menggambarkan kegigihan Maria untuk mengajar ilmu kepada masyarakat di sekitarnya.

Maria Zaitun terus mengajar semua orang membaca al-Faihah. Mulamula Maria Zaitun menyuruh Tasmin baca. KemudianMakcik Lang, selepas Makcik Ijuk pula baca. Akhir sekali Makcik Jarah yang baca. Maria Zaitun mendapai Makcik Jarah, Makcik Lang dan Makcik Ijuk boleh membaca dengan Baik. (Fatimah Busu: 242)

Kegigihan Maria mengajar orangorang di Hutan Beringin ia tunjukkan dengan ketidakputusasaannya menggunakan fasilitas yang serba terbatas. Sekalipun mereka menulis menggunakan arang ia jalani pula, hingga ia mendapat sebuah papan yang telah dibuang oleh pemiliknya. Ia tak segan meminta papan tersebut yang kemudian ia perbaiki guna menambah sarana mengajar.

Dalam Trilogi Khadijah Hashim, Datin Maria juga membantu Hapipah, pembantunya untuk menuntut ilmu sekalipun

Watak dan Perjuangan Perempuan dalam Novel-novel Karya Penulis Perempuan Indonesia... 
hanya melalui kursus dan kelas malam hari. Ia percaya bahwa ilmu pengetahuan, betapapun akan mampu mengubah nasib seseorang.

Para tokoh dalam novel-novel Malaysia memperjuangkan hak-hak mereka dalam memilih jodoh. Dalam Trilogi Khadijah Hashim tokoh Sakinah sangat terperanjat tatkala Mak Uda menyatakan bahwa dia sangat cocok "jadi menantu aku" (298). Di jaman modern ini masyarakat masih percaya pada perjodohan, yang tentu saja sudah tidak sesuai dengan demokrasi yang dipercayai Sakinah.

Dalam novel yang sama, Hapipah, sekalipun sudah punya pacar sendiri, juga berhadapan dengan keinginan orang tuanya untuk menjodohkan dengan Johan.

"Apa kurangnya Johan? Dia pun guru juga, lulusan universiti pula" kata Haji Mansur, ayah Hapipah. "Kahwin dengan saudara sendiri harta tidak tumpah ke orang lain," tambah ibunya, Hajah Kamariah.(Hashim:32)

Pemaksaan perjodohan yang dilakukan oleh orang tuanya ia tolak mentahmentah karena dalam pemikirannya hal tersebut bertentangan dengan hak azasi manusia yang paling hakiki.

Para tokoh dalam novel-novel Malaysia berjuang melawan kekerasan (seksual) patriarki yang membelenggu mereka. Dalam Syumul, Sovisir melawan deraan suaminya yang kecuali pemabuk berat juga penganiaya tak berperikemanusiaan. Di sisi lain suami Sovisir berpendapat bahwa isterinya adalah haknya, sehingga ia bebas mengatur sekehendak hatinya:

“Bohong!”Jerit lelaki itu, kebengisan." Kau lupa, engkau perempuan aku. Harta aku. Sebagai harta aku, hanya aku seorang sahaja yang boleh menggunakan engkau. Bila engkau langgar undang-undang dunia seperti itu berarti kau memang cari fasal dengan aku! Memang cari hanas! (Azmah Nordin: 204)

Perjuangan Sovisir adalah perjuangan melawan kekerasan dalam rumah tangga yang sangat menyiksa. Sekalipun kekuasaan dan egoisme laki-laki yang direpresentasikan oleh suaminya sangatlah kuat, ia yang awalnya pasrah menyerah, pada akhirnya memberontak dan mencari ikhtiar untuk keluar dari jeratan tersebut.

Maria Zaitun dalam Salam Maria juga memperjuangkan hak-hak bagi Maznah yang dalam keadaan mengandung telah ditinggalkan oleh suaminya. Sekalipun Masnah bukan perempuan yang "baikbaik saja", Maria tidak pndang bulu. BaginyaMasnah tetap korban ketidakadilan terhadap perempuan. Maria juga memperjuangkan hak-hak Rohidah dan Arifah yang telah diperkosa oleh lelaki tidak bertanggung jawab.

Dua tokoh dalam novel-novel Malaysia yang diteliti berjuang gigih dalam ranah ekonomi, seperti ditunjukkan oleh Hapipah dalam Trilogi Khadijah Hashim yang sangat aktif berdagang untuk menghidupi keluarganya. Dengan berbekal keterampilannya, dengan tekun dan pantang penyerah ia berhasil menjadi pengusaha yang sukses.

Demikian pula Dr. Farhana dalam Haruman Kencana. Keteguhannya menjadikan ia berhasil menjadi pemimpin perusahaan minyak wangi halal bagi kamu muslim. Perusahaan yang ia bangun dari kecil bahkan telah melakuan ekspansi ke Timur Tengah dan Arab.

\section{SIMPULAN}

Para tokoh perempuan dalam novelnovel Indonesia yang diteliti ini memiliki perwatakan yang kompleks dan multidimensional yang memberi kemungkinan berbagai sikap bagi pembaca untuk menanggapi. Para tokoh yang digambarkan realis dalam kegetiran hidup mereka 
menghadapi problema patriarki tersebut merupakan potret kehidupan yang jujur.Para tokoh perempuan ini memiliki watak yang kuat (kecuali Nayla), cerdas, berani, kritis, dinamis dan mandiri. Mereka bukan termasuk tipe perempuan pasif yang bergantung kepada orang lain. Mereka (June, Yasmin) merayakan kebebasan menentukan pasangan dan partner seksual mereka secara berlebihan, sehingga merasa tidak bersalah meninggalkan pasangan resmi mereka. Dalam beberapa hal para tokoh perempuan ini membangun citra positif perempuan yang dibutuhkan dalam upaya pemberdayaan perempuan, tapi dalam beberapa hal lain mereka lemah, terpojok dan menjadi korban (Nayla, Yasmin, June). Para tokoh perempuan ini menghadapi problemproblem diskriminasi, subordinasi dan kekerasan fisik maupun simbolik yang muncul dalam masyarakat patriarki pada umumnya, dan mereka baik secara langsung maupun tidak melakukan upayaupaya emasipasi dan perjuangan untuk menaklukkannya. Sebagian dari para tokoh (terutama Nayla) digambarkan sebagai korban ketimpangan gender yang sangat serius sehingga menjadikannya pribadi yang limbung.

Para tokoh perempuan dalam novelnovel Malaysia yang diteliti memiliki pribadi yang kuat. Mereka digambarkan sebagai perempuan yang cerdas dan intelektual. Mereka juga mandiri secara finansial, serta memiliki kemerdekaan dan keberanian untuk membuat keputusankeputusan yang penting dalam hidup mereka. Bebarapa di antara mereka (Maria dan Farhana) menunjukkan jiwa kepemimpinan yang baik dan menjadi panutan bagi masyarakat di sekitarnya. Mereka bertakwa dan sekalipun berbenturan dengan pengaruh kehidupan modern tetap teguh menjalankan kehidupan beragamanya. Para perempuan ini, terutama Maria menghadapi tantangan dan problema patriarki yang cukup serius, dan dengan kegigihan berhasil mengatasi, sekalipun harus mengorbankan nyawanya sendiri.

Kedua kelompok novel telah menunjukkan jati diri sebagai novel feminis karena mampu keluar dari stereotipe tokoh perempuan yang domestik, pasif dan bergantung. Mereka adalah perempuan-perempuan yang aktif, mandiri, berani tangguh yang berjuang melawan subordinasi yang mengerdilkan kaum perempuan. Penggambaran watak dan perjuangan perempuan sedemikian dalam novel-novel yang ditulis para novelis perempuan Indonesia maupun Malaysia awal abad 21 merefleksikan kesadaran gender penulisnya dan upaya-upaya mereka untuk menyadarkan masyarakat pembaca yang rata-rata masih hidup dalam alam patriarki. Pada saat yang sama novel-novel ini sekaligus juga merupakan potret realita pahit kehidupan masyarakat patriarki.

Jika dibandingkan, tampak bahwa novel-novel yang ditulis novelis perempuan Indonesia lebih memperlihatkan realita kekerasan, terutama kekerasan seksual terhadap perempuan yang brutal (misalnya Nayla, Yasmin). Para tokoh perempuan Indonesia tampak lebih terpengaruh dan bahkan merayakan budaya barat yang lebih memberi kebebasan (mis June, Yasmin, Nayla), sedangkan tokoh perempuan dalam novel-novel Malaysia tampak lebih mempertahankan jati diri kemelayuan dan nilai-nilai kearifan lokal mereka (misalnya Maria). Novel-novel Indonesia lebih menyuarakan masyarakat kebanyakan di mana tokoh-tokohnya adalah manusia biasa (Nayla, June) yang memiliki problema yang lebih personal, sementara dalam novel Malaysia para tokoh merupakan orang-orang yang istimewa yang perbuatannya memiliki dampak lebih luas (Dr. Farhana, Kencana, Maria).

Watak dan Perjuangan Perempuan dalam Novel-novel Karya Penulis Perempuan Indonesia... 


\section{UCAPAN TERIMAKASIH}

Artikel ini diangkat dari laporan hasil penelitian yang didanai oleh Lembaga Penelitian Universitas Negeri Yogyakarta. Ucapan terimakasih disampaikan kepada Dr. Hajah Siti Khairiah Mohd Zubir dari Universiti Pendidikan Sultan Idris, Malaysia, dan Sri Sumardingisih, M.Pd. dari Universitas Negeri Yogyakarta yang telah menjadi mitra peneliti (co researcher) serta pembaca banding penelitian ini.

\section{DAFTAR PUSTAKA}

Bronwyn, Davies. 1993. "The Sense Children Make of Feminist Stories" dalam Reading in Literary Literacy. Melbourne: Deakin University Press
Fairclough, Norman. 1992. Language and Power. London and New York: Longman.

Fiske, John. 1995. “Understanding Pop Culture". Reading the Popular. 1-13.

Fiske, John. 1982. Introduction to Communication Studies. New York: Routledge.

Gilbert, Pam and Taylor, Sandra. 1991. Fashioning the Feminine: Girls Pop Culture and Schooling. Sydney

Hollindale, Peter. 1988. "Ideology and Children's Book" in Signal 55

Morris, Pam. 1993. Literature and Feminism. Cambridge : Blackwell,

Stephens, John. 1992. Language and Ideology in Children's Fiction. London: Longman. 